\title{
Contribution of Academic Self-Concept and Parental Social Support to Learning motivation
}

\author{
Ayunil Ummi ${ }^{1}$, Sufyarma Marsidin', Mudjiran ${ }^{3}$ \\ 1,2,3 Universitas Negeri Padang \\ *Corresponding author, e-mail: ayunillubis@gmail.com
}

\begin{abstract}
Contribution of academic self-concept and parental social support to learning motivation. This research is motivated by the low student motivation. Academic self-concept and parental social support are thought to have an effect on student motivation. This study aims to describe: (1) academic self-concept, (2) parental social support, (3) student learning motivation, (4) Contribution of academic self-concept to student learning motivation, (5) contribution of parental social support to student learning motivation, and (6) the contribution of academic self-concept and parents' social support together on learning motivation. This research uses a descriptive correlational quantitative method. The study population was students of class $X$ and XI at SMKN 6 Padang, totaling 983 students, a sample of 284 students, who were selected by using cluster random sampling technique. The results of this study indicate that academic self-concept and parental social support together have a significant effect on learning motivation at SMKN 6 Padang by $64.5 \%$. The implications of the results of this study can be used as a needs analysis in making Guidance and Counseling service programs at SMKN 6 Padang.
\end{abstract}

Keywords: Academic Self-Concept, Parents Sosial Support, learning motivation

How to Cite: Ummi, A., Marsidi, S., Mudjiran, M. (2020). Contribution of Academic SelfConcept and Parental Social Support to Learning motivation. International Journal of Applied Counseling and Social Sciences. 2 (1): pp. 94-99. DOI: https://doi.org/10.24036/005403ijaccs

\section{Introduction}

Studying is compulsory for all Indonesian citizens. Law No.20 of 2003 Chapter I Article 1 Paragraph 18 states that: "Compulsory education is the minimum education program that must be followed by Indonesian citizens on the responsibility of the government and local governments". The obligation to study in Chapter VIII Article 34 Paragraph 1 which states: "Every citizen aged 6 (six) years can join the compulsory education program.

Learning is an effort made by individuals through interaction with their environment (Iskandar, 2009). Prayitno, Wibowo, Marjohan, Mugiarso, \& Ifdil (2014) explained that learning is an effort to find out something new. Uno (2013) describes learning as a change in behavior that occurs after students participate in teaching and learning, namely learning outcomes in the form of mastery of abilities and skills.

Studying is compulsory for all Indonesian citizens. Law No.20 of 2003 Chapter I Article 1 Paragraph 18 states that: "Compulsory education is the minimum education program that must be followed by Indonesian citizens on the responsibility of the government and local governments". The obligation to 
study in Chapter VIII Article 34 Paragraph 1 which states: "Every citizen aged 6 (six) years can join the compulsory education program"

Learning is an effort made by individuals through interaction with their environment (Iskandar, 2009). Prayitno, Wibowo, Marjohan, Mugiarso, \& Ifdil (2014) explained that learning is an effort to find out something new. Uno (2013) describes learning as a change in behavior that occurs after students participate in teaching and learning, namely learning outcomes in the form of mastery of abilities and skills.

Iskandar (2009) states that the learning process is characterized by changes in behavior due to new experiences, so that students gain experience, appreciation, habits, and competence. The desired behavior change from the learning process must have a strong motivation from within students, in order to achieve the desired learning goals.

Motivation is something that causes students to take steps, keeps students going, and determines where students try to go (Slavin, 2011). Waruwu (2006) states that the role of motivation is very important in the learning process, students who do not have sufficient motivation certainly have a low interest in learning subject matter, because students will not be motivated to find the information needed and make efforts to deepen the subject matter.

Biggs and Moore (1993) explain that student learning motivation is caused by students 'expectations for success, students' way of appreciating the activity process, and the results obtained. That is the importance of motivation in learning that must be possessed by students, but the description of facts and phenomena that occur in the field shows things that are not expected. Based on research conducted by Waruwu (2006), there are many complaints about the decline in student learning motivation, both at the elementary, middle and college levels.

Research conducted by Elmirawati, Daharnis, and Syahniar (2013) described the learning motivation of students at SMA Negeri 1 Singingi, revealing that student learning motivation was in the moderate category. According to the news portal Klik Sumbar (2014) forty students ranging from Elementary School (SD) unior High School (SMP) and Senior High School (SMA) were arrested by the Civil Service Police Unit (Satpol PP) of Padang City on June 12, 2014. Dozens students were secured because they were caught truant during the Teaching and Learning Process (PBM). In fact, eight of them were caught playing koa and domino card gambling in the area of Jalan Azizi, Andalas, Padang City.

Motivation to learn arises because of intrinsic factors or factors from within students and extrinsic factors caused by encouragement and desire for needs, hopes and ideals, or factors that come from outside of students in the form of appreciation, student environmental conditions, and learning activities interesting (Iskandar, 2009). Jahja (2011) classified two types of motivation, namely: (1) intrinsic motivation, namely motivation that grows from within humans in the form of a strong impulse that comes out of him and provides the ability to do work without coercion. (2) extrinsic motivation, namely motivation that grows due to external encouragement given by parents, teachers, and the community.

student environmental conditions affect motivation to learn. The student's environmental conditions are supported by parents. Parental support is thought to be a factor that influences student learning motivation, both positive and negative. Parental support in creating a learning atmosphere for students is very influencing because in general students are still dependent on their parents, both moral and material support. Tan, Ismanto \& Babakal (2013) research stated that parental support has a significant relationship to student learning motivation. Parental support provided to students is generally in the medium category. Most of the school age children have motivation to learn in the medium category.

Learning motivation is influenced by internal factors, namely students' self-concept. Sunaryo (2004) states that self-concept is an individual's way of seeing his or her personality perfectly, physically, emotionally, intellectually, socially, and spiritually, including individual perceptions of the nature and potential they have, individual interactions with others and their environment, values. relating to experiences and objects, as well as goals, hopes, and desires. 
Learning motivation can also be influenced by internal factors, namely students' self-concept. Academic self-concept is a set of mental control instruments because it affects students' thinking abilities. Academic self-concept can make students more confident and feel confident in their abilities because the academic self-concept itself includes how individuals behave, feel and evaluate their abilities (Marsh, 2003).

Their academic self-concept makes students more confident and feel confident in their ability to behave, feel and evaluate themselves. Students who have a positive academic self-concept perceive, assess, and feel themselves positively, while students who have an academic self-concept perceive, assess, and feel themselves bad.

Handling negative self-concept problems in students and low support provided by parents related to students' low learning motivation. Guidance and Counseling (hereinafter referred to as BK) as an integral part of the educational process. BK is seen as an educational process for learning to have positive thoughts to increase student motivation, so that students have good achievement. Based on this description, it is necessary to have an in-depth study of the factors that influence student learning motivation. Counselors can optimize guidance and counseling services in schools to improve students' academic self-concept.

\section{Method}

This research uses a descriptive correlational quantitative method. The study population was students of class XI and XII SMKN 6 Padang, amounting to 983 people, a sample of 284 people, who were selected by cluster random sampling technique. The instrument used was a Likert scale model. Data were analyzed using descriptive statistics, simple and multiple regression. Assisted data analysis by using the SPSS program version 20.00 .

\section{Results and Discussion}

The data in this study included academic self-concept variables (X1), parental social support (X2), and learning motivation student $(\mathrm{Y})$. The following is a description of the research data.

\section{Data Description}

\section{Academic self-concept}

The description of the academic self-concept data totaling 284 respondents can be seen in Table 1.

Tabel 1. Distribution and Percentage of Academic Self Concepts

\begin{tabular}{clcc}
\hline Score & Category & Frequency & $\%$ \\
\hline$\geq 84$ & Very High & 0 & 0 \\
$68-83$ & High & 215 & 75,70 \\
$52-67$ & Moderate & 69 & 24,30 \\
$36-51$ & Low & 0 & 0 \\
$\leq 35$ & Very Low & 0 & 0 \\
& Total & 284 & 100 \\
\hline
\end{tabular}

Table 1 above shows that most students have a high self-concept in learning, which is $75.70 \%$, some other students are in the medium category, namely $24.30 \%$, So, on average, students' selfconcept is in the high category.

\section{Parental Social Support}

Description of parental social support data, amounting to 284 respondents, can be seen in Table 2. 
Table 2. Parental Social Support

\begin{tabular}{clcc}
\hline Score & \multicolumn{1}{c}{ Category } & Frequency & $\%$ \\
\hline$\geq 84$ & Very High & 55 & 19 \\
$68-83$ & High & 203 & 72 \\
$52-67$ & Moderate & 55 & 19 \\
$36-51$ & Low & 0 & 0 \\
$\leq 35$ & Very low & 0 & 0 \\
& Total & 284 & 100 \\
\hline
\end{tabular}

Table 2 above shows that most students received high support from parents for education, namely $72 \%$, some other students received very high support, namely $19 \%$, some other students received moderate support, namely $19 \%$. So, on average parental support is in the very high category.

\section{Learning Motivation}

Table 3. Learning Motivation

\begin{tabular}{clcc}
\hline Score & \multicolumn{1}{c}{ Categori } & Frequency & $\%$ \\
\hline$\geq 84$ & Very High & 3 & 1 \\
$68-83$ & High & 221 & 78 \\
$52-67$ & Moderate & 60 & 21 \\
$36-51$ & Low & 0 & 0 \\
$\leq 35$ & Very Low & 0 & 0 \\
& Total & 284 & 100 \\
\hline
\end{tabular}

Table 3 above shows that most of the student's learning motivation is in the high category, namely $78 \%$, the medium category is $21 \%$, and the very high category is $1 \%$. So, on average, student learning motivation is in the high category.

\section{Conclusion}

Based on the findings and discussion academic self-concept contributes to the learning motivation of students of SMK Negeri 6 Padang by $48.6 \%$. That is, the higher the contribution of academic selfconcept, the higher the student's learning motivation, or vice versa if the academic self-concept is negative, it will result in lower student learning motivation. Parents' social support contributed $55.8 \%$ to the learning motivation of students of SMK Negeri 6 Padang. This means that the higher the contribution of parental social support, the higher the student's motivation to learn, or vice versa if the social support of parents is low, it will result in lower student learning motivation. Academic selfconcept and parental social support contributed $64.2 \%$ to the learning motivation of students at SMK Negeri 6 Padang. That is, the level of student learning motivation is not only influenced by one variable (academic self-concept and parental social support), but is jointly influenced by academic self-concept and parental social support. In other words, the higher the academic self-concept and the higher the parents' social support, the higher the student's motivation to learn. This means that the variables of academic self-concept and parental social support will be more effective if they contribute together as predictors of student learning motivation 


\section{References}

Ahmadi, A. (1991). Sosiologi Pendidikan. Jakarta: Rineka Cipta.

Bahri, A., dan Corebima, A.D. (2015). "The Contribution of Learning Motivation and Metacognitive Skill on Cognitive Learning Outcome of Students within Different Learning Strategies". Journal of Baltic Science Education, Vol. 14, No. 4: 487-500.

Biggs, B.J., dan Moore, P.J. (1993). “Process of Learning”. Melbourne: Prentice Hall Bong, M., dan Clark, R.E. 1999. "Comparison between Self-Concept and Self-Efficacy in Academic Motivation Research". Educational Psychologist, (Onlin), Vol. 34, Issue 3, (http://www.tandfonline.com/doi /abs/10.1207/s15326985ep3403_1,

Dimyati dan Mujiono. (2009). Belajar dan Pembelajaran. Jakarta: Rineka Cipta.

Djamarah, S.B. (2011). Psikologi Belajar. Jakarta: Rineka Cipta.

Elmirawati, Daharnis, dan Syahniar. (2013). "Hubungan Antara Aspirasi Siswa dan Dukungan orangtua Dengan Motivasi Belajar Serta Implikasinya terhadap Bimbingan Konseling". EJournal Konselor, (Online), Vol. 2, No. 1, (http://ejournal.unp.ac.id/ index.php/konselor/article/view/871/726,

Firdaus, N.A., Nugroho, A.H., dan Meydianasari, L. (2013). Hubungan Konsep Diri dengan Motivasi Belajar. Jurnal Keperawatan AKPER 17 Karanganyar (Online), Vol. 1, No. 1, (http://jurnal.akper17.ac.id/ index.php/JK17/article/ view/7/8,)

Gunawan, A.W. (2005). Apakah IQ Anak Bisa Ditingkatkan dan Masalah-masalah Lain Seputar Pendidikan Anak yang Sering Dihadapi Orangtua dan Guru. Jakarta: Gramedia Pustaka

Utama. Hasan, M.I. (2010). Pokok-pokok Materi Statistik 2: Statistik inferensif. Jakarta: Bumi Aksara

Hasbullah. (2001). Dasar-Dasar Ilmu Pendidikan. Jakarta: RajaGrafindo Persada.

Hidayati, S. (2011). "Hubungan Dukungan Orangtua dengan Prestasi Belajar Siswa Kelas VII MTs AlMukarromin Wadak-Kidul Duduksampeyan Gresik". Tesis tidak diterbitkan. Malang: Universitas Negeri Malang.

Iskandar. (2009). Psikologi Pendidikan: Sebuah orientasi baru. Ciputat: Gaung Persada. Jahja, Y. (2011). Psikologi Perkembangan. Jakarta: Kencana Prenada Media. Kraebber, S.L., dan

Greenan, J.P. (2012). "The Relationship between Self-Concept and Self-Ratings of Generalizable Skills of Students in Postsecondary Career and Technical Programs". Journal of Career and Technical Education, Vol. 27, No. 1.

Lumsden, L.S. (1994). "Student Motivation to Learn”. ERIC Learinghouse on Educational Management. (Online), http://people.ucsc.edu/ gwells/Files/ Courses_Folder/documents/ Lumsden.StudentMotivationToLearn.pdf, diakses 25 Februari 2015).

Manning, M.A. (2007). "Self-Concept and Self-Esteem in Adolescents". National Association of School Psychologists, (Online), Musbikin. I. (2012). Mengatasi Anak Mogok Malas Belajar. Yogyakarta: Laksana.

Ormrod, J. E. (2008). Educational Psychology. America: Pearson Education.

Prayitno, Wibowo, M.E., Marjohan, Mugiarso, H., dan Ifdil. (2014). Pembelajaran Melalui Pelayanan BK di Satuan Pendidikan. Padang: UNP Press.

Rahmi, A. (2012).“Konsep diri, Motivasi Belajar Siswa Membolos dan Implikasinya terhadap Layanan Bimbingan dan Konseling". Tesis tidak diterbitkan. Padang: Program Pascasarjana UNP Padang.

Sanchez, F.J.P. dan Roda, M.D.S. (2003). Relationships between Self-concept and Academic Achievement in Primary Students. Electronic Journal of Research in Educational Psychology and Psychopedagogy. Vol. 1 No. 1, 95-20.

Santrock. (2003). Adolencence Perkembangan Remaja. Terjemahan oleh Achmad Chusairi dan Juda Damanik. Jakarta: Erlangga.

Sarafino, E.P. dan Smith, T.W. (2011). Health Psychology: Bio psychosocial interaction. New York:

John Willey dan Sans Inc. Slavin, R.E. (2011). Psikologi Pendidikan (Edisi Kesembilan Jilid 2). Terjemahan oleh Marianto Samosir. Jakarta: Indeks. 
Steers, R.M. (1987). Motivation and Work Behavior. Singapore: Chong Moh. Sunaryo. (2004). Psikologi untuk Keperawatan. Jakarta: EGC.

Syah, M. (2012). Psikologi Belajar. Jakarta: Rajawali Pers

Tan, J.H., Ismanto, A.Y., dan Babakal, A. (2013). “Hubungan antara Dukungan Orangtua dengan Motivasi Belajar pada Anak Usia Sekolah Kelas IV dan V di SD Negeri Kawangkoan Kalawat". E-journal keperawatan (e-Kp). Vol. 1, No. 1: 1-8. 